\title{
To have your cake and eat it too: accountability under a preferential voting system
}

According to the principle of economic voting, voters punish incumbents when the economy is doing badly and reward them with votes when it is doing well. As more and more countries have become a testing ground for this US-born theor $y^{1}$, researchers have found this relationship to be far more complex, often hinging on the specificities of electoral and political systems ${ }^{2}$. Although scholars have drawn distinctions between the majoritarian and PR settings, few have pointed to the important distinction within the PR setup - open vs. closed list arrangements. Informed by findings in the economic voting literature, this research attempts to fill this void by showing how economic conditions allow voters to distinguish between high/low performers and effectively attribute responsibility under an open-list PR system. By integrating open-list design into the model of accountability, this study transforms the way we think about the very act of voting. The calculus of voting is altered from the typical one- stage decision where a voter decides which party to support to a two-stage process with a voter also deciding which candidate to choose.

1 J. Fearon, Electoral Accountability and the Control of Politicians, [in:] Democracy, Accountability, and Representation, ed. A. Przeworski, S. Stokes, B. Manin, Cambridge1999; J. Ferejohn, Incumbent Performance and Electoral Control, "Public Choice" 50: 5-25; G. Kramer, Short Term Fluctuations in US Voting Behavior:1896-1964, "American Politicas Science Review" 65: 131-43.

2 R. Alvarez, R. Michael, J. Nagler, J. R. Willette, Measuring the Relative Impact of Issues and the Economy in Democratic Elections, "Electoral Studies" 19: 237-253; C. J. Anderson, Economic voting and political context: a comparative perspective, "Electoral Studies" 19: 151-170; R. M. Duch, R. Stevenson, Voting in Context: How Political and Economic Institutions Condition the Economic Vote, Cambridge 2008; G. B. Powell, G. D. Whitten, A Cross-National Analysis of Economic Voting: Taking Account of the Political Context, "American Journal of Political Science" 37(2): 391-41. 


\section{The Literature}

Competitive elections are at the heart of the contemporary notion of democracy ${ }^{3}$. Their central role is to ensure adequate representation by allowing voters to evaluate and influence the government, thereby holding officials accountable to the individuals who elected them. Accountability is achieved when citizens are able to discriminate between unrepresentative and representative government and can sanction accordingly ${ }^{4}$. Thus, voters hold governments to account by punishing under-performance and rewarding those who perform as promised 5 .

Easily quantifiable, economic performance has served generations of scholars as a criterion for voters' decisions about whether to reward or punish incumbents. Bad economic times are associated with reduced support for the governing powers while good economic results are thought to help them in gathering electoral support ${ }^{6}$. The economic voting argument was first developed and successfully tested in the context of the US electoral system ${ }^{7}$. Looking predominantly at the performance and approval ratings of presidents, researchers have created economic voting models which have led them to conclude that economic performance determines presidential votes ${ }^{8}$.

3 G. B. Powell, Elections as Instruments of Democracy, New Haven 2000; J. Schumpeter, Capitalism, Socialism, and Democracy, New York: Harper 1947.

4 S. Stokes, B. Manin, Democracy, Accountability, and Representation, Cambridge 1999; G. B. Powell, Elections as Instruments of Democracy, New Haven 2000.

5 J. Fearon, Electoral Accountability and the Control of Politicians, [in:] Democracy, Accountability, and Representation, ed. A. Przeworski, S. Stokes, B. Manin, Cambridge1999; J. Ferejohn, Incumbent Performance and Electoral Control, "Public Choice" 50: 5-25.

6 R. M. Duch, R. Stevenson, Voting in Context: How Political and Economic Institutions Condition the Economic Vote, Cambridge 2008; M. S. Lewis-Beck, M. Paldam, M. Paldam, Economic Voting: an Introduction, "Electoral Studies" 19: 113-121; R. M. Alvarez, J. Nagler, J. R. Willette, Measuring the Relative Impact of Issues and the Economy in Democratic Elections, "Electoral Studies" 19: 237-253.

7 G. Kramer, Short Term Fluctuations in US Voting Behavior:1896-1964, "American Politicas Science Review" 65: 131-43; S. Goodman, G. Kramer, Comment on Arcelus and Melzer, the Effect of Aggregate Economic Conditions on Congressional Elections, "American Political Science Review” 69: 1255-1265; E. Tufte,.. Political Control of the Economy, Princeton1978; M. S. Lewis-Beck, M. Stegmaier, Economic Determinants of Electoral Outcomes, "Annual Review of Political Science” 3: 183-219.

8 M. S. Lewis-Beck, M. Stegmaier, Economic Determinants of Electoral Outcomes, "Annual Review of Political Science" 3: 183-219.

9 With some controversies arising as to the motivations of voters, i.e. whether they are prospective or retrospective, sociotropic or egocentric 
To have your cake and eat it too: accountability under a preferential voting system... $\mid 169$

Nevertheless, research into economic voting in US Congressional elections and, even more so, in other countries, has not yielded conclusive results ${ }^{10}$. In response, scholars have attempted to refine the traditional model.

Consequently, it has been shown that open economies experience lower levels of economic voting due to citizens recognizing the limited influence governing parties have on an economy affected by global trends ${ }^{11}$. In the post-communist countries of Eastern Europe, economic voting has been related rather to parties'legacies (old vs. new - regime parties) than to parties' incumbency status ${ }^{12}$. Another strain of research has suggested that economic voting depends on the type of incumbent party and voters' evaluation of the goals this party aims to serve ${ }^{13}{ }^{14}$. Economic voting has also been explained in terms of individual-level constraints such as limits to cognition and information and the impact of values and evaluations ${ }^{15}$.

An influential strain of research has examined the "clarity of responsibility" argument by introducing variables that condition the economic vote by reflecting the political and economic context as well as institutional features of electoral and political systems ${ }^{16}{ }^{17}$.

10 D. A. Hibbs, Solidarity or Egoism, Arhaus 1993; A. Alesina, J. Londregan, H. Rosenthal, A Model of the Political Economy of the United States, "American Political Science Review" 87:12-33; M. S. Lewis-Beck, M. Stegmaier, Economic Determinants of Electoral Outcomes, "Annual Review of Political Science" 3: 183-219; D. Sanders, The Real Economy and the Perceived Economy in Popularity Functions: How Much Do Voters Need to Know? "Electoral Studies" 19: 275-294; M. Paldam, P. Naanestad, Into Pandora's Box of Economic Evaluations. A Study of the Danish Macro VP-Function 1986-1997, "Electoral Studies" 19: 123-140; C. J. Anderson, The End of Economic Voting? Contingency Dilemmas and the Limits of Democratic Accountability, "Annual Review of Political Science" 10: 271-96;

11 R. M. Duch, R. Stevenson, Voting in Context: How Political and Economic Institutions Condition the Economic Vote, Cambridge 2008; T. Hellwig, Interdependence, Government Constraints, and Economic Voting, "The Journal of Politics" 63(4): 1141-1162.

12 J. Tucker, Regional Economic Voting: Russia, Poland, Hungary, Slovakia, and Czech Republic, 1990-1999, New York 2006.

13 K. Hamann, Linking Policies and Economic Voting: Explaining Reelection in the Case of the Spanish Socialist Party, "Comparative Political Studies" 33(8): 1018-48.

14 According to this view, left wing parties are punished by voters for high levels of unemployment while right wing parties are punished for high levels of inflation .

15 C. J. Anderson, The End of Economic Voting? Contingency Dilemmas and the Limits of Democratic Accountability, "Annual Review of Political Science" 10: 271-96.

16 G. B. Powell, G. D. Whitten, A Cross-National Analysis of Economic Voting: Taking Account of the Political Context, "American Journal of Political Science" 37(2): 391-41; C. J. Anderson, Economic voting and political context: a comparative perspective, "Electoral Studies"19: 151-170; R. M. Alvarez, J. Nagler, J. R. Willette, Measuring the Relative Impact of Issues and the Economy in Democratic Elections, "Electoral Studies" 19: 237-253

R. M. Duch, R. Stevenson, Voting in Context: How Political and Economic Institutions Condition the Economic Vote, Cambridge 2008.

17 In addition, Anderson $(2007,284)$ hints at the possible use of elections as a selection tool. He argues that clarity of responsibility is an important factor only if voters perceive viable 
This argument underscores the general differences between majoritarian and PR systems. It suggests that majoritarian systems display a higher level of economic voting (and thus accountability) because of their propensity to produce one-party governments. Conversely, PR systems that often produce minority and coalition governments are more likely to experience lower levels of economic voting because it is difficult for voters to assign responsibility to a specific party or actor ${ }^{18}$. Thus, it should not be surprising that we find higher levels of economic voting in the majoritarian US and lower levels in PR countries such as France, Germany, Norway, Italy, etc.

While the differences between the majoritarian and PR systems have become widely recognized and acknowledged, few have paid attention to a more nuanced distinction within the PR arrangements, which can have a profound impact on whether we detect economic voting at all. PR systems differ in how much freedom they allow voters in determining the final slate of candidates. Closed-list PR systems allow voters only to choose between party lists. Voters have no influence on the ordering of this list, and as a consequence, no influence on whom from this list advances to parliament should their party collect enough votes. Under an open-list arrangement, voters are free to indicate their preference for a specific candidate on the list and, in doing so, rearrange the party lists and influence who becomes elected. Meanwhile, PR open-list systems have become increasingly popular, especially with new democracies in Eastern Europe and Latin America.

Thus, it is troubling that the economic voting literature has not given much more thought to the distinction between open- and closed-list designs ${ }^{19}{ }^{20}$. Instead, scholars

alternatives other than the incumbent. This implies that voters not only sanction or punish incumbents but also evaluate them and compare them to their opponents. In this case, they not only use retrospective but also prospective considerations. They express their preferences for the future rather than expressing their opinions about the past.

18 G. B. Powell, Elections as Instruments of Democracy, New Haven 2000; G. B. Powell, G. D. Whitten, A Cross-National Analysis of Economic Voting: Taking Account of the Political Context, "American Journal of Political Science" 37(2):391-41; T. Hellwig, Interdependence, Government Constraints, and Economic Voting, "The Journal of Politics" 63(4):1141-1162; C. J. Anderson, Economic voting and political context: a comparative perspective, "Electoral Studies" 19: 151-170.

19 J. Zielinski, K. Slomczynski, G. Shabad, Electoral Control in New Democracies: The Perverse Incentives of Fluid Party Systems, "World Politics" 57: 365-95; V. Smeets, F. Warzynski, Creation, Job Destruction and Voting Behavior in Poland, "European Journal of Political Economy" 22: 503-519.

20 Certainly, plenty has been written about the consequences of preferential voting as it relates to voters casting a personal vote. It has been widely acknowledged and confirmed empirically that preferential voting arrangements are more indicative of personal voting than closed-list PR systems (Cain et al. 1987; Taagapera and Shugart 1989; Ames 1992). Since voters decide not only which party but also which candidate will receive a legislative seat, candidates have to compete with their colleagues from the same party. A party label is not as important a cue for a voter and hence, candidates have the incentive to cultivate the personal vote. A more fine-grained analysis of differences among electoral systems illustrates that the incidence of 
continue to treat and conceptualize accountability in the same way, irrespective of the type of list arrangement. Meanwhile, the traditional approach, when applied to openlist systems, ignores a host of important information which may be potentially useful to scholars and researchers. As the next section shows, this is related not only to how we conceptualize accountability but also, and possibly more importantly, to how we conceptualize the very act of voting itself.

\section{The Traditional vs. Open-List Economic Voting Model}

Traditional voting models evaluate accountability under PR systems based on a simple, one-stage voting decision where voters, based on their retrospective assessment, decide exclusively whether to cast their votes for the governing party. Figure 1 illustrates the voters' choice under this conceptualization of voting and accountability.

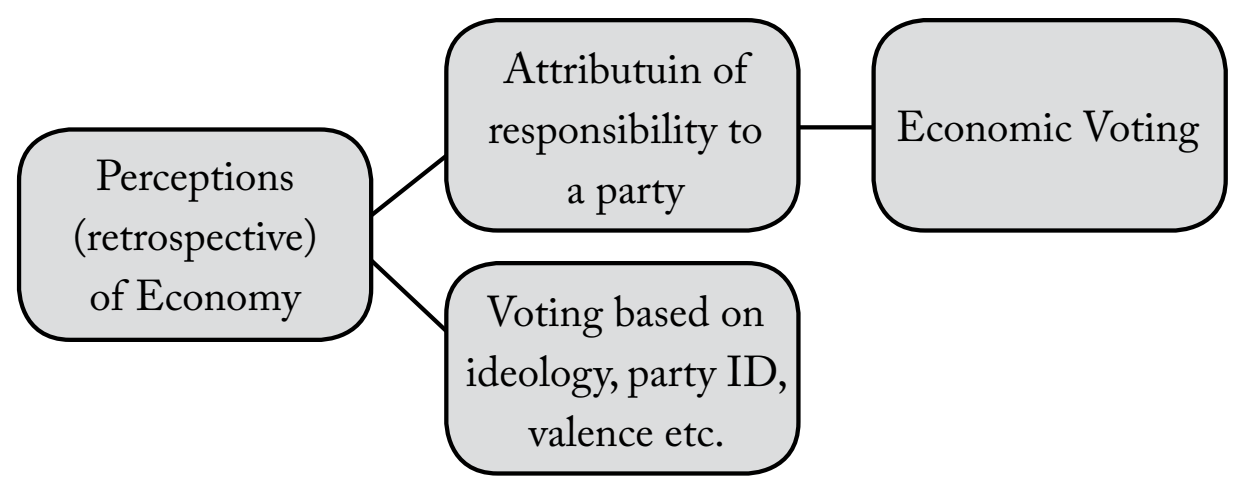

Figure 1 The Traditional Model of Voting and Accountability

personal voting is also related to details of the preferential ballot, vote pooling procedure, type of vote cast, and district magnitude (Cain et al. 1987; Carey and Shugart 1995). Where an open ballot is used, party leaders have less control over the candidate list and, hence, the system should be more prone to personal voting. Pooling votes across parties or candidates, on the other hand, encourages candidates to build not only their own but also their party's reputation. Researchers are, however, not unanimous on the effects personal voting has on democracy. While some argue that preferential voting systems result in greater voter satisfaction, others warn against it impeding the effectiveness of political parties and, in effect, having a negative impact on democratic elections (Vid. Farrell and McAllister 2004; Pereira and de Silva 2009 but Sartori 1976; Pereira and Renno 2003). And while some caution against the detrimental effects of preferential systems and personal voting on the levels of corruption (Reed 1994, Chang 2005), others find the opposite effect when open - and closed- list systems are compared (Kunicova and Rose-Ackerman 2002; Persson and Tabellini 2003). 
Under this traditional one-stage model two findings can emerge. Firstly, one can find that voters, based on their perceptions of the economy, attribute responsibility for economic outcomes to the incumbent party either by blaming it for bad economic performance and voting against it or, when economic performance is satisfactory, by continuing to support it. In this situation, one concludes that the economic voting model applies. Secondly, one may find that voters do not vote on the basis of their economic perceptions. Instead, they vote based on other factors such as their party affiliation, the ideological proximity of a party, the personality of a party leader or a party candidate etc. $^{21} 22$. In this case, economic voting hypotheses fail.

This is precisely where introducing the two-stage approach gains in importance and has the potential to broaden our understanding of accountability under an open-list system of PR. The traditional conceptualization of voting, while very much appropriate for closed-list PR systems, fails to acknowledge the important difference preferential systems make for voters. By incorporating the second stage of the voting decision into the model of voting, this research extends the narrow scope of considerations that voters are allowed under the traditional economic voting models.

Figure 2 shows how crucial the second stage of voting is for the voting calculus under preferential voting systems. The two-stage voting model acknowledges the greater number of options available to voters when allocating responsibility for economic outcomes. We learn not only about factors that influence voters' decisions at the party- but also at the candidate level ${ }^{23}$.

The key advantage of the two-stage voting model is reflected in situations where voters do not attribute responsibility for economic outcomes to a party at the first stage but choose to vote for a party based on other considerations. When this is the case, the

21 J. Zielinski, K. Slomczynski, G. Shabad, Electoral Control in New Democracies: The Perverse Incentives of Fluid Party Systems, "World Politics" 57: 365-95; V. Smeets, F. Warzynski, Creation, Job Destruction and Voting Behavior in Poland, "European Journal of Political Economy" 22: 503-519; R. M. Duch, R. Stevenson, Voting in Context: How Political and Economic Institutions Condition the Economic Vote, Cambridge 2008.

22 Research confirms that non-economic bases for voting decisions are an important element. Political cleavages along social and ideological lines often influence voting choices (Whitefield 2000). Non-economic factors are especially strong among new democracies where, as argued by Duch (2000), the risk of voting for an unknown or disliked opposition may be greater than the risk of voting for incumbents. Therefore, voters may be inclined to vote for incumbents despite bad economic performance. Thus, when ideological, social or risk considerations prevail, the traditional economic voting hypothesis fails, which suggests low levels of economic accountability.

23 This model does not have to be used exclusively for economic voting but is also applicable to research on accountability in general. After quantifying a different basis for accountability than the economic, researchers can test for it at two different stages and for both candidate and party accountability. 
traditional economic voting model fails. The two-stage model, however, has the capability to detect whether the economy plays a role in the selection of a specific candidate. If so, the economic voting model still holds.

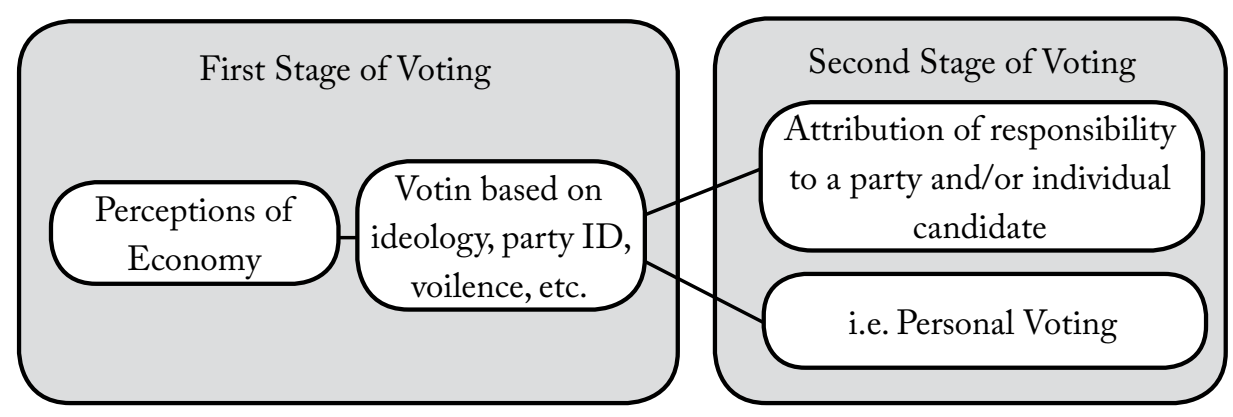

Figure 2 Two-Stage Voting Model

Thus, in preferential voting PR systems, economic voting may still take place even when a voter's main decision about which party to support is not based on economic performance. Moreover, if conceptualized accordingly, economic voting at the second stage may potentially relate to holding not only parties but also individual candidates accountable.

\section{The Economic Voting Hypotheses and the Two-Stage Voting Model}

The standard economic voting hypothesis against which economy-based accountability is measured implies that "voters punish the incumbent if the economy is doing badly by withdrawing their support and reward the incumbent with votes when the economy is doing well". The hypothesis fits well when voting is conceived as a one-stage process but does not reflect the aforementioned second stage of voting for open - list PR systems. Potentially, under open-list arrangements, voters can hold parties accountable even when voting for the parties' candidates, if their choice of candidate relates to the party's and/or candidates' performance in office.

One can measure a governing party's success by looking at the relationship between the number of incumbents running from a party list and the number of incumbents reelected to parliament ${ }^{24}$. Voters vote for the party in power, however, they systematically prefer candidates who were not incumbents in the outgoing parliament. In line with the main assumptions of the theory of economic voting, we should see a positive relationship

24 Of course, incumbents may also be punished by their parties, which will add to the measurement error but should not invalidate the results. 
between economic performance and the number of reelected incumbents. Thus, the accountability hypothesis at the second stage of the voting decision is as follows:

H1 Party/Candidate Accountability Hypothesis: The greater the economic downturn, the greater the number of incumbents from the governing party's list fail to be reelected.

However, operationalizing accountability by looking exclusively at aggregate incumbent performance is problematic on two counts. Firstly, most of the information is lost as non-incumbent performance is disregarded. Secondly, since we consider the final count of incumbent success for a party, we are not really able to distinguish whether (and to what extent) voters punish the party or individual candidates.

Thus, I consider a second approach that relates to the list placement of the candidates and has the added capacity to distinguish between party and candidate accountability. ${ }^{25}$ Since the main difference between preferential and non-preferential PR voting systems is voters' ability to interfere with the order of candidates then, in contexts where parties are in charge of assembling the initial electoral list, voters' decisions to rearrange this list should be considered an important indicator of accountability.

When party accountability is considered, I hypothesize that voters pay special attention to the candidates listed at the top of their lists. These are usually parties' "showcase candidates." These candidates include party leaders, former MP's, famous personalities, etc. When voters are happy with the outcomes, they are more likely follow a party's preferences and cross the first person on the list. When they are not happy with the outcomes, they are more likely to look into the party's choice of candidate order and punish the top "showcase" candidates, sending their party a message of dissatisfaction. Consistently, with the retrospective voting argument, this relationship should only hold for the governing party's candidates. If voters punish or reward the top candidates for economic results, we have an incidence of economic voting. The subsequent second stage economic voting hypothesis is as follows:

H2 Party Accountability Hypothesis: When the economy is doing badly, candidates of a governing party listed at the top of the list ("showcase candidates") are more likely to fall from their initial position due to preferential voting and are more likely to stay in their position if the economy is doing well.

25 Note that when it is operationalized this way, economic voting assumes that the party is involved and has an influence on list creation. It is not the case in all PR open-list systems, however. In Brazil, for example, a party does not determine the initial list order. Instead, the initial order of candidates on a list is determined by chance. 
In addition, when list placement is considered, we are able to separate party accountability from the accountability of individual candidates by considering their incumbency status. The difference between this and the earlier approach is that now we consider each candidate individually whereas for hypothesis 1 , we have considered them in an aggregate. Now, incumbent candidates are considered along with non-incumbents. If the economic voting argument holds with respect to individual candidates, we should see incumbents faring worse when the economy is declining. Thus, my last second-stage economic voting hypothesis states:

H3 Individual Accountability Hypothesis: When the economy is doing badly, incumbent candidates are more likely to fall from their initial position on the list than they are when the economy is doing well.

It is unclear what our expectations should be here about how incumbents from governing parties differ from non-governing parties in this regard. On the one hand, one can imagine non-governing party incumbents faring better when the economy is doing badly, since their party should not be associated with those negative outcomes. On the other hand, in a PR setting, with lower levels of clarity of responsibility, all incumbents could feel the anger of voters who, as the economy declines, blame this decline on all incumbents and are ready for personal changes in parliament.

\section{Testing the Second Stage of Voting}

I have chosen Poland to test my theory of two-stage economic voting. Poland adopted an open-list PR system in 1989 and has continued to use it ever since. Electoral rules require voters to cast a preferential vote. A vote for a party only is not allowed (See Appendix 1 for an example of a Voting Ballot in Poland) ${ }^{26}$. At the same time, a degree of party control remains since it is up to the party to determine the initial ordering of the lists (essential for testing my Party Accountability Hypothesis). Top candidate placements are strictly controlled by all parties' leaderships and include party "showcase candidates" who are supposed to gain votes, and consequently, seats in parliament

26 A vote is counted both towards the final ordering of the candidates on the list and the final vote count for the party list that will establish whether this list will be awarded a legislative seat(s). The final ordering depends on the number of votes each candidate receives in the elections. The candidate who collects the most votes is assigned the first position on the list and is the first one to receive a legislative seat if the whole list was able to collect enough votes in the district and if it crossed the national legislative threshold (5 percent for one party and 8 percent for a coalition). If the total votes in the district are sufficient to ensure two seats, the next candidate on the list- the one who received the second highest number of votes- is awarded a legislative seat etc. 
Poland is also one of the most researched among Central and Eastern European countries with scholars struggling to distinguish a clear pattern according to which accountability works and whether or not economic voting takes place ${ }^{27}$. Potentially, distinguishing between two stages of voting under Polish open-list PR may produce interesting results confirming or dispelling the presence of economic voting and adding to the debate.

Since Poland has held relatively few elections since 1989, I have followed the method of regional-level data, comparing the results each party achieved in an electoral district in two consecutive elections. Initiated by Pacek and Fidmurc, developed and refined by Tucker and later used by Zielinski et al., the distinction between regional performance within each election is a great tool for ensuring greater variance and providing important insights into the phenomenon of economic voting ${ }^{28}$.

\section{Incumbent Success as a Determinant of Accountability}

I was able to compile regional electoral and economic data for 4 elections in the period between 1997 and 2007. To test my Party/Candidate Accountability Hypothesis (H1) the dependent variable is operationalized as the total number of party incumbents reelected from a district. As mentioned before, the main decision that voters have to make is whether they will vote for the incumbent candidate. This support for an individual on aggregate renders the voters' approval of a party.

27 J. Bell, Unemployment Matters: Voting Patterns during the Economic Transition in Poland 1990-1995, "Europe Asia Studies" 49(7): 1263-1291; J. Fidmurc, Political Support for Reforms: Economics of Voting in Transition Countries, "European Economic Review" 44:1491-1513; J. E. Jackson, J. Klich, K. Poznanska, 2003a. "Democratic Institutions and Economic Reform: the Polish Case.” British Journal of Political Science 33:85-108; B. W. Mach, J. E. Jackson, Employment Change, Attitude Evolution and Voting During Poland's Transition: Longitudinal Evidence, "European Journal of Political Economy" 22: 472-502; A. Owen, J. Tucker, Past is Still Present: Micro-level Comparisons of Conventional vs. Transitional Economic Voting in Three Polish Elections, "Electoral Studies" 29 (1): 25-39; A. Pacek, Macroeconomic Conditions and Electoral Politics in East Central Europe, "American Journal of Political Science" 38: 732744; D. V. Powers J. H. Cox, Echoes From the Past: the Relationship Between Satisfaction with Economic Reforms and Voting Behavior in Poland, "American Political Science Review" 91(3): 617-633; S. Stokes, B. Manin, Democracy, Accountability, and Representation. Cambridge 1999; V. Smeets, F. Warzynski, Job Destruction and Voting Behavior in Poland, "European Journal of Political Economy” 22: 503-519; J. Tucker Regional Economic Voting: Russia, Poland, Hungary, Slovakia, and Czech Republic, 1990-1999, New York 2006; J. Zielinski, K. Slomczynski, and Goldie Shabad. 2005. "Electoral Control in New Democracies: The Perverse Incentives of Fluid Party Systems." World Politics 57: 365-95.

28 In Poland the regional division for which economic data is available across elections is based on the administrative unit called voivodship. The division into voivodships, however, has not been uniform over the period. In 1999, an administrative reform was introduced which reduced the number of voivodships from 49 to 16 . The data in my dataset reflects these changes with the administrative regions being coded differently for the elections that took place before and after 1999. 
Consistent with the assumption of the traditional retrospective voting hypotheses, only the governing party and its candidates are scrutinized, i.e. should be punished (its incumbent candidates fail to be reelected) if the economy is doing badly and rewarded if the economy is doing well. Consequently, I include an independent dichotomous variable to distinguish the governing (Prime Minister's) party in elections (PM Party). ${ }^{29}$ The general expectation is that, with all else equal, incumbent parties are able to gather more votes than other parties, considering their access to the different types of political resources that incumbency grants.

However, incumbency status alone is not indicative of economic voting. According to the economic voting literature, the economy should only have an effect on the governing parties. Therefore, my main variable of interest is the interaction between the economic and the governing party variable.

Of the possible economic variables (GDP, income levels, inflation, and unemployment), I have decided to exclusively use unemployment to operationalize economic performance in Poland. Unlike GDP, unemployment data has been available for each election. Because of the regional approach, I have not been able to include inflation as a measure of economic performance since inflation rates are rarely specified on a regional level. Income measures, on the other hand, are problematic since they have not been adjusted for inflation.

I have operationalized unemployment as an independent variable in terms of percentage change in its levels between the year preceding elections and the election year. As opposed to the electoral data, which is at an electoral district level, unemployment data is available only at the voivodship level, i.e. each candidate in a district in a voivodship is assigned the value for this voivodship (see Appendix 2 to compare the differences in the level of divisions, note that districts cannot be shared between voivodships, thus, assigning the voivodship's unemployment levels to districts is relatively straightforward) ${ }^{30}$. I predicted that as unemployment rises, a governing party's vote declines (PM Party X Unemployment).

29 The choice to operationalize a governing party as a PM Party is somewhat arbitrary given the coalitional nature of Polish governments over the period. An alternative would be to code all parties that have been in the governing coalition as incumbents. However, in the Polish case, such a practice could have proven problematic given the frequent changes and even breakdowns in the governing coalitions. Operationalizing the party of the Prime Minister as the governing party is, thus, more straightforward and clear cut. Consequently, for the 1997 elections the incumbent party is the Democratic Left Alliance (SLD), for the 2005 elections, it is again the Democratic Left Alliance (SLD) and for the 2007 elections it is the Law and Justice party (PiS).

30 In Poland, the regional division for which economic data is available across elections is based on the administrative unit called voivodship. The division into voivodships, however, has not been uniform across the years. In 1999 an administrative reform was introduced, which reduced the number of voivodships from 49 to 16 (Compare Figures 2 and 3 in Appendix 2). 
In addition, I apply a control for the total number of incumbents who are running for reelection. Some of the incumbents may have decided not to run for different reasons or a party may have decided not to run them on their list. Also, I add a party strength variable that acts as a control for the share of votes (voteshare) a party received in a district. This is to account for smaller parties that naturally have fewer incumbents running on their list as well as for the number of total candidates a party ends up having elected. Since vote share and the number of elected candidates are highly correlated, I can only include one of them and the first is more precise. I use a natural log of the share of votes a party won in a district. This variable is operationalized as the share of votes the whole party list received in a district and has the same value for each candidate on each party list in a particular district. For a similar reason, given the differences between regions and elections, I apply a control for district magnitude. Since there is a large disparity between districts, I also use a natural $\log$ in this case ${ }^{31}$. Larger districts mean that more candidates are elected there, and thus, more candidates are running. As a result there is a greater probability of incumbents running in a district of a large magnitude. Lastly, I apply a control for the specific circumstances of each election by introducing election dummies. The result is a dataset where the unit of analysis is the number of reelected incumbents in a district in a specific election (1997,2001,2005, or 2007). Each observation represents a party running in a district in each of these elections.

Since my dependent variable is fairly normally distributed and approximates a continuous variable, I use OLS regression to estimate my model (Table 1). Unemployment on its own has no effect; however, it has the expected effect for a governing party. Even though the effect is small $(3.4 \%)$ it is highly statistically significant $(p<0.001)$. The higher the increase in unemployment levels, the fewer incumbents from a governing party succeed. This result is confirmed by a positive and statistically significant interaction term, both when the statistical significance is provided for the joint effect of the economy and the incumbency/governing party's status.

The data in my dataset reflects these changes with the administrative regions being coded differently for the elections that took place before and after 1999. Figure 1 in Appendix 2 presents the current division into electoral districts.

31 (district magnitude in Poland has varied depending on the year of election and number of districts between a minimum of 3 and a maximum of 19) 
To have your cake and eat it too: accountability under a preferential voting system... 179

\begin{tabular}{|c|c|}
\hline \multicolumn{2}{|c|}{$\begin{array}{c}\text { Table } 1 \\
\text { List Effects of Change in Unemployment }\end{array}$} \\
\hline Incumbents Running & $\begin{array}{l}0.396^{* * *} \\
(0.03)\end{array}$ \\
\hline Governing Party & $\begin{array}{l}-0.572^{* * *} \\
(0.08)\end{array}$ \\
\hline Unemployment Change & $\begin{array}{l}-0.002 \\
(0.00)\end{array}$ \\
\hline Unemp. X Governing Party & $\begin{array}{l}-0.032^{* * * *} \\
(0.00)\end{array}$ \\
\hline Voteshare $(\ln )$ & $\begin{array}{l}0.621^{* * *} \\
(0.02)\end{array}$ \\
\hline District Magnitude (ln) & $\begin{array}{l}0.561^{* * *} \\
(0.07)\end{array}$ \\
\hline Elections 2001 & $\begin{array}{l}0.515^{*} \\
(0.21)\end{array}$ \\
\hline Elections 2005 & $\begin{array}{l}0.363^{* * *} \\
(0.17)\end{array}$ \\
\hline Elections 2007 & $\begin{array}{c}0.152^{*} \\
(0.08)\end{array}$ \\
\hline Constant & $\begin{array}{l}-1.623^{* * *} \\
(0.15)\end{array}$ \\
\hline \multicolumn{2}{|l|}{ Joint Effect } \\
\hline $\begin{array}{c}\text { Unempchng + Unemp.Chng, X } \\
\text { Gov. Party }\end{array}$ & $\begin{array}{l}-0.034^{* * *} \\
(0.01)\end{array}$ \\
\hline $\begin{array}{c}\text { Gov.Party + Unemp.Chng X Gov. } \\
\text { Party }\end{array}$ & $\begin{array}{l}-0.605^{* * *} \\
(0.08)\end{array}$ \\
\hline $\mathrm{R}$-sqr & 0.638 \\
\hline $\mathrm{N}$ & 1852 \\
\hline
\end{tabular}

In addition, the results reveal a puzzling finding that the governing party is always at a disadvantage. Normally, with all else equal, we would predict the opposite, i.e. that governing parties would have the incumbent advantage ${ }^{32}$. This counterintuitive finding

32 R. S. Erikson, The Incumbency Advantage in Congressional Elections, "Polity" 3, p. 395-405; M. Marsh, The Voters Decide?: Preferential Voting in European List Systems, "European Journal of Political Research" 13: 365-378; A. Gelman, G. King, Estimating Incumbency Advantage without Bias, "American Journal of Political Science" 4: 1142-64; S. W. Desposato, J. R. Pet- 
could be potentially attributed to the hyper-accountability associated with Central and Eastern European countries ${ }^{33} 34$.

Thus, the economic voting hypothesis is confirmed when the second-stage of voting is considered. Polish voters have the ability to punish their parties, even if they decide to vote for them. They can do so by expressing their approval/disapproval by voting for or against these parties' incumbent candidates. Is this relationship confirmed when all candidates for legislative office are considered and when we are able to distinguish between party and candidate accountability? Let us turn to consideration of an alternative measurement of party and candidate accountability.

\section{List placement as a Determinant of Accountability}

Given that the main difference between preferential and non-preferential PR voting systems is voters' ability to interfere with the order of party lists, voters' decisions to rearrange this list should be considered an important indicator in determining accountability. Consequently, my dependent variable is conceptualized as a change from the initial position of a candidate (position on the list as decided by the party) to a final position as decided by the voters who cast a preferential vote ${ }^{35}$. The unit of analysis is the value of change from the initial to the final position for a candidate in an electoral district in parliamentary elections. The dependent variable can take a maximum value of positive 35 and a minimum value of negative 30 , which means that the most a candidate ever fell down the list was by 30 positions and the most a candidate advanced up the list was by $35^{36}$. The value of 0 indicates that a person remained at the initial position as assigned

rocik, The Variable Incumbent Advantage: New Voters, Redistricting, and the Personal Vote, "American Journal of Political Science" (47):18-32; J. Karp, Candidate Effects and Spill-Over in Mixed Systems: Evidence from New Zealand, "Electoral Studies" 28: 41-50; B. Ames, Electoral Strategy Under Open-List Proportional Representation, "American Journal of Political Science" 39: 406-433.

33 A. Roberts, Hyperaccountability: Economic voting in Central and Eastern Europe, "Electoral Studies" 27: 533-546.

34 To check for the possible effect of a party's association with an old or new regime, I have divided my dataset and run my model for new and old regime parties separately The models (included in the Appendix) have only to an extent confirmed the hypotheses advanced by Tucker. Only the new regime parties seem to be punished for bad economic results. For the old regime parties, unemployment levels do not seem to matter at all.

35 As mentioned earlier, in Poland voters do not have the choice whether they want to vote for a party list or for a specific candidate on this list. Instead they have to vote for a specific person on the list. When talking to the party leaders, I was informed that about $40 \%$ of the total votes casts are considered preferential/personal votes as opposed to those who vote for the first person on the list as a sign of party (and not specific candidate) support.

36 Such extreme changes from initial list positions are possible thanks to the high magnitude of some legislative districts and electoral law provision which allow parties to compose lists with the number of candidates reaching up to twice the district magnitude. Thus, at its maximum in the Warsaw I district, parties are able to compose a list with up to 38 candidates. Parties try 


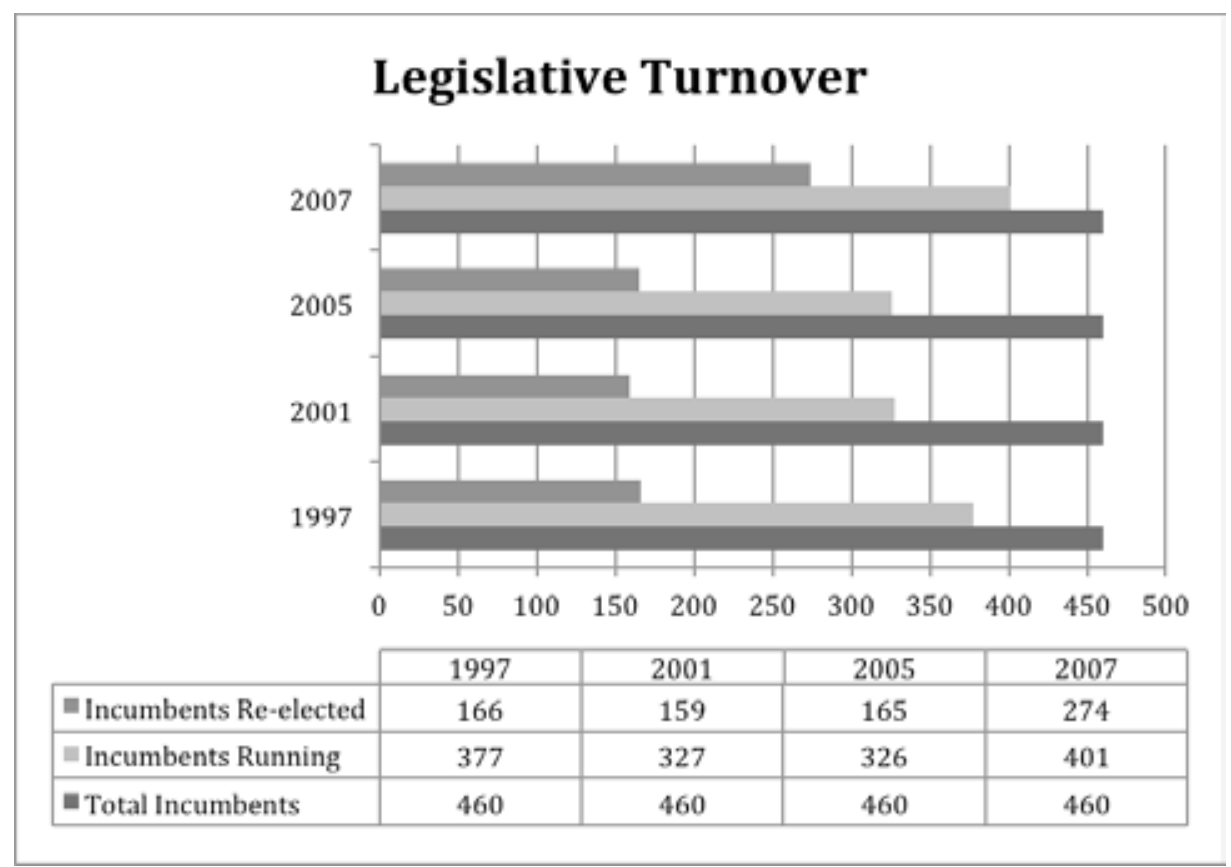

Figure 3

by the party. Zero is also the median value for the dependent variable (for a summary statistic of all variables in this model see Appendix 3).

I follow the operationalization of the remaining variables from the earlier model. I include incumbency variables for both the party (PMParty) and the candidates (Incumbent) and use the change in Unemployment levels to gauge economic performance. Since the expectations about the effect of unemployment on voting within the framework of economic voting cannot be derived without considering the effect of incumbency variables, I combine the variables accordingly (IncumbentXUnemployment and PMPartyXUnemployment) which reflects the notion that voters reward or punish incumbent candidates and parties based on retrospective evaluations of economic results. I also include important control variables from the previous model, such as district magnitude and party share of the vote in the previous election.

In addition, to control for the electoral strength of a party at the time of elections, I create a new instrumental variable that should approximate a party's electoral attractiveness to the voters. One can imagine a situation in which a party which was very popular in previous elections, having gained a lot of votes or even having become a governing party, losing its support over the term. I operationalize this variable as legislative

to use this opportunity since every vote, even if cast for the last candidate on the list, adds to a party's vote count, which in turns determines how many (if any at all) seats a party will get in the parliament. 
turnover, which is the rate at which a party's incumbent candidates are reelected. Figure 1 presents legislative turnover across elections ${ }^{37}$.

Lastly, I apply a control for candidates' gender. Research has found that gender is an important criterion for voting ${ }^{38}$. In general, women usually perform worse than men in elections. However, it has also been found that women benefit from the preferential vote $^{39}$.

All in all, my dataset includes data on four Polish legislative elections from 1997 to 2007. The unit of analysis is a change in the position of a candidate on a party list in a particular district in specific elections and the statistical model appears as follows:

$$
\begin{aligned}
& \text { Y }=\beta_{0}+\beta_{1} \text { INCUMBENT }+\beta_{2} \text { DIST.MAG }+\beta_{3} \text { VOTE SHARE }+\beta_{4} \text { PM PARTY }+ \\
& \beta_{5} \text { FEMALE }+\beta_{6} \text { UNEMPLOYMENT }+\beta_{7} \text { INCUMBENT xUNEMPLOYMENT } \\
& +\beta_{8} \text { PM PARTY } x \text { UNEMPLOYMENT }+\beta_{9} \text { TURNOVER }+\beta_{10} \text { ELECTION } 1997 \\
& +\beta 11 \text { ELECTION } 2001+\beta 12 \text { ELECTIONS } 2005+\beta_{13} \text { ELECTIONS } 2007+\text { ei }
\end{aligned}
$$

When testing for accountability, we first want to see how the economy affects changes in positions on the list. Since I conceptualize my dependent variable (change in the initial position on the list) in such a way that it approximates a linear variable (runs from negative 30 to positive 35), I could consider using OLS regression to test my hypotheses. However, since position may have a profound impact on how voters cast their votes, we should consider running a model for each position separately ${ }^{40}$. Once new dependent variables are construed for each position, their distribution is dramatically different and OLS es-

37 With the notable exception of the 2007 elections, only about 50 percent of the incumbent candidates who decided to run again were routinely re-elected. If all incumbent candidates are calculated the re-election rate is only 30 percent. A possibly more direct and better way to measure a party's attractiveness would be to compare the electoral results for consecutive elections in a district. However, the data that exists does not allow for such operationalization. This is due to two main factors. First, redistricting in 1999 causes a lot of confusion as to which areas should be included in calculating the changes in electoral results. Secondly, the changes among parties (changes in names, breakdowns, and coalitions between parties) make this task nearly impossible for the 1997-2007 elections.

38

39 Also, Polish parties seem to perceive the differences between voters' attitudes towards men and women as some parties have taken particular interest in how women are situated on the list and some of my interviewees believed that preferential voting especially benefited those women listed early on the list. Thus, to control for the possible impact of candidates' gender, I include a variable distinguishing between female and male candidates 40 On the impact of positions on voting vid. Zielinski et al. 2005; Miller and Krosnick 1998. 
timation cannot be used. ${ }^{41}$ Instead, I apply a maximum likelihood estimation that allows us to look for the probabilities of candidates dropping down or advancing up the list.

I chose to look at the first three positions when considering party and candidate accountability. This choice is arbitrary, though directed by important considerations. Firstly, it is pragmatic given the sheer number of positions on the lists in Polish elections. Secondly, districts and parties vary greatly in the number of candidates they allow on their lists and by using the first three, I "standardize" the districts to an extent. Thirdly, the first three positions are most likely to display the parties' "showcase candidates". This is not to say that the analysis could not be expanded to further positions once a qualitative study had determined that they had been assigned as showcase candidates as well.

Since my modified dependent variable indicates how each candidate's position on the list was changed by voters, I need the absolute values of the previous dependent variable (change in position) for each position. Since this is always a positive number, I need to account for a possible fall by those initially listed second or third on the list. This is straightforward for the first position. For the second position, an absolute value for a fall and advance by one position would be the same and therefore, the variable created is abs (position change -1). For the third position, a similar process is applied though now we just take the abs(position change -2 ) for those listed third ${ }^{42}$.

The new dependent variable requires a different regression estimation technique since it includes only positive values and is skewed to the left for each of the three positions. Considering the distribution of the variables, I choose negative binomial estimation for all three positions (For a detailed explanation of the choice of estimation technique and variable distributions see Appendix 5).

Table 2 presents the results. The main variables of interest that measure accountability are the interaction terms between the economy and the governing party and the economy and the incumbency status of a candidate, which relate to party and individual candidate accountability respectively. The results are mixed. They indicate statistical significance for each of the interaction terms for the candidates listed in the first position. For those listed second, only incumbents are significantly affected by changes in unemployment while for those listed third, only candidates from the governing party seem to be held accountable by voters.

41 Running OLS regression in the first instance may be a good way to quickly scan the data and results (vid. Appendix 4 for the OLS regression results and description).

42 Calculated this way, for the first position my new dependent variable - absolute change in position - takes the value of 0 if a candidate does not experience any change, 1 if they fall by one position, 2 if they fall by two positions etc. For the second position, the value of 0 means that they actually advance one position, 1 means they stay in the same spot, 2 means they fall one position etc. For the third position, 0 means that they go up by two positions, 1 by one position, 2 means they stay in the third position, 3 means they fall to the fourth position etc. 


\begin{tabular}{|c|c|c|c|}
\hline \multicolumn{4}{|c|}{$\begin{array}{c}\text { Table } 2 \\
\text { Absolute Change in Position (Negative Binomial Estimation) }\end{array}$} \\
\hline & Position 1 & Position 2 & Position 3 \\
\hline \multirow{2}{*}{ Incumbent } & $-0.809^{* * *}$ & $-0.515^{* * *}$ & $-0.498^{* * *}$ \\
\hline & $(0.21)$ & $(0.07)$ & $(0.08)$ \\
\hline \multirow{2}{*}{ District Magnitude (ln) } & $0.549^{* *}$ & $0.273^{\text {***k }}$ & $0.319^{* * *}$ \\
\hline & $(0.20)$ & $(0.06)$ & $(0.05)$ \\
\hline \multirow{2}{*}{ Vote share $(\ln )$} & 0.081 & -0.015 & -0.021 \\
\hline & $(0.06)$ & $(0.02)$ & $(0.01)$ \\
\hline \multirow{2}{*}{ Governing Party } & -0.308 & 0.068 & 0.020 \\
\hline & $(0.27)$ & $(0.07)$ & $(0.06)$ \\
\hline \multirow{2}{*}{ Female } & $0.431^{*}$ & $-0.191^{* * * *}$ & $-0.098^{*}$ \\
\hline & $(0.18)$ & $(0.05)$ & $(0.04)$ \\
\hline \multirow{2}{*}{ Unemployment } & 0.015 & 0.002 & 0.005 \\
\hline & $(0.01)$ & $(0.00)$ & $(0.00)$ \\
\hline \multirow{2}{*}{ Incumbent X Unemployment } & $-0.021^{*}$ & $-0.007^{*}$ & 0.001 \\
\hline & $(0.01)$ & $(0.00)$ & $(0.00)$ \\
\hline \multirow{2}{*}{ Gov. Party X Unemployment } & $0.049^{* * *}$ & -0.006 & -0.005 \\
\hline & $(0.01)$ & $(0.00)$ & $(0.00)$ \\
\hline \multirow{2}{*}{ Not-reelected Incumbents } & 0.032 & 0.015 & -0.027 \\
\hline & $(0.06)$ & $(0.02)$ & $(0.01)$ \\
\hline \multirow{2}{*}{ Election 1997} & $1.463^{*}$ & 0.081 & 0.092 \\
\hline & $(0.64)$ & $(0.18)$ & $(0.15)$ \\
\hline \multirow{2}{*}{ Election 2005} & 0.183 & -0.106 & -0.002 \\
\hline & $(0.25)$ & $(0.07)$ & $(0.06)$ \\
\hline \multirow{2}{*}{ Election 2007} & -0.390 & -0.187 & 0.068 \\
\hline & $(0.67)$ & $(0.18)$ & $(0.15)$ \\
\hline \multirow{2}{*}{ Constant } & $-3.185^{* * *}$ & $0.378^{*}$ & $0.577^{* * *}$ \\
\hline & $(0.63)$ & $(0.19)$ & $(0.16)$ \\
\hline
\end{tabular}

Numbers in parentheses are standard errors; $* p<0.05, * * p<0.01, * * * p<0.001$

However, the statistical significance of the interaction terms should not be measured unconditionally. An effect of a variable may be significant at some levels of the variable and insignificant at others. Table $2 \mathrm{~A}$ includes the results of the joint effect for the economy and candidate incumbency as well as the economy and the candidate's governing party status. It shows an interesting pattern as those listed in the first position are more likely to drop to lower positions when there has been an increase in unemployment if they are from the governing party. This effect is consistent with my Party Accountability Hypothesis (H2). The "showcase candidates" of the governing party are punished for poor economic performance, which implies that economic voting under preferential voting systems exists. For those 
listed in the second and third positions, on the other hand, this is not the case, i.e. the conditional effect of unemployment is not statistically significant. Incumbency has a significant effect on candidates in all positions but there is no joint effect of unemployment on incumbents. Thus, the Candidate Accountability Hypothesis (H3) does not find confirmation ${ }^{43}$.

\begin{tabular}{cccc}
\hline \multicolumn{4}{c}{$\begin{array}{c}\text { Table 2A } \\
\text { Absolute Change in Position } \\
\text { Joint Effect }\end{array}$} \\
\hline & Position 1 & Position 2 & Position 3 \\
\hline PM Party + Gov. X Unemployment & -0.259 & 0.062 & 0.0146 \\
& $(0.26)$ & $(0.07)$ & $(0.06)$ \\
\hline Unemployment + Gov. X & $0.06^{* * * *}$ & -0.004 & -0.0002 \\
Unemployment & $(0.02)$ & $(0.01)$ & $(0.00)$ \\
\hline Incumbent + Incumbent X & $-0.830^{* * * *}$ & $-0.522^{* * *}$ & $-0.497^{* * *}$ \\
Unemployment & $(0.21)$ & $(0.07)$ & $(0.08)$ \\
\hline Unemployment + Incumbent X & -0.006 & -0.006 & 0.006 \\
Unemployment & $(0.017)$ & $(0.005)$ & $(0.005)$ \\
\hline lnalpha constant & $1.215^{* * * *}$ & $-1.358^{* * * *}$ & $-1.692^{* * * *}$ \\
& $(0.12)$ & $(0.08)$ & $(0.08)$ \\
\hline Prob>=chi-sgrt & 0.000 & 0.000 & 0.000 \\
\hline Pseudo R-sgrt & 0.043 & 0.017 & 0.018 \\
\hline $\mathrm{N}$ & 1851 & 1849 & 1850 \\
\hline
\end{tabular}

Numbers in parentheses are standard errors; $* p<0.05, * * p<0.01, * * * p<0.001$

Since maximum likelihood estimates are difficult to interpret in substantive terms, I calculate predicted values to learn the substantive effect of the economy on candidates' positions on the list. ${ }^{44}$ The results of simulations for each of the models (for each of the positions) are presented in Table 3. The predicted values relate to one's fall or advancement on the list. Considering how the dependent variable was constructed, the interpretation of the predicted values for the first position is straightforward. Values in proximity to zero

43 Given the prominent position of the economic voting literature, that stresses the importance of parties' legacies in new democracies, I have also checked whether old and new regime hypotheses are applicable for individual accountability, i.e. whether new regime candidates are negatively affected by a decline in economic performance as opposed to old-regime candidates, who should be affected positively by an economic downturn. I have run the regression for old and new regime parties separately but have not noticed any effect that would be consistent with old/new regime hypotheses.

44 I use "Clarify," which is a simulation technique to present statistical results using STATA which by default draws 1000 sets of parameters. Next, the simulated parameters are converted into, in this case, predicted values (Tomz, Wittenberg, and King 2003). 
indicate a candidate staying in the first position. This is also the most common occurrence. However, in some cases, the predicted mean value is much higher than zero (albeit not reaching one). Are the differences consistent with economic voting hypotheses?

The simulations were performed for specific values of variables of interest, i.e. candidate incumbency, party incumbency and unemployment. I have also distinguished between different elections and run separate simulations for each of them. Since we are really interested in the effect of unemployment, I have firstly calculated differences between minimum and maximum values of unemployment change for each year, i.e. for 1997 the maximum change was $-10.07 \%$ and the minimum was $-45.15 \%$; for the 2001 elections the maximum change was $25.27 \%$ and the minimum change was $8.81 \%$; for the 2005 elections, the maximum change was $11.46 \%$ and the minimum change was $3.21 \%$; and for 2007 the maximum change was $-12.72 \%$ and the minimum was $-32.2 \%$. ${ }^{45}$

For the sake of interpretation, it is important to note that the minimum value for unemployment indicates a decrease in the unemployment level while the maximum value indicates an increase in the unemployment level. Consequently, according to economic voting hypotheses we should expect that, with all else equal, higher unemployment change should produce greater dissatisfaction among voters and therefore a greater fall down the list. Conversely, lower unemployment change should cause candidates to rise up the list.

Other than unemployment, I have used different values for incumbency and governing party status to see whether and how they influence the impact unemployment has (or does not have) on a candidate's position on the list. Thus, I provide results for changes in unemployment for incumbent and non-incumbent candidates for both governing and non-governing parties. The theory of (retrospective) economic voting suggests that we should expect unemployment to have the greatest impact on incumbent candidates and governing party candidates since these candidates are under voters' scrutiny for their performance in office.

Table 3 presents the results of the simulations for each position. As expected, unemployment has the greatest impact for those who are first on their party's list. It is important to note that positive values in this case are negative in effect, i.e. candidates value higher positions on the list which are lowest in numerical value (i.e. position no. 1 is the most sought after and highest position despite the fact that it has the lowest value). Adding to this value indicates candidates falling down the list. The worsening of economic outcomes impacts almost all top-listed candidates and causes them to fall down the list. Only the top-listed incumbent candidates from a non-governing party are not affected by negative changes in the economy. On the other hand, those incumbents of a governing party listed second on a list are benefiting from worsening economic condi-

45 I have used unemployment maxima and minima for each respective election as opposed to using one overall maximum (25.57\%) and overall minimum (-45.15\%) to avoid out of sample predictions (although the authors of "Clarify" state that out of sample predictions are possible to make with this software) (Tomz, Wittenberg and King 2003). 
To have your cake and eat it too: accountability under a preferential voting system... $\mid 187$

tions. Thus, the simulations add an interesting caveat to our findings. It seems as if there is a reshuffle of the top two positions on governing parties' lists. When the economy declines, voters are less likely to vote for the top candidate. They do not, however, look far for a replacement but go ahead and choose the second person on the list.

\begin{tabular}{|c|c|c|c|c|}
\hline \multicolumn{5}{|c|}{$\begin{array}{c}\text { Table } 3 \\
\text { First Differences in Final List Position conditioned on the value } \\
\text { of the change in unemployment (ranging from minimum to } \\
\text { maximum change, i.e. from best to worst economic conditions) }\end{array}$} \\
\hline Variable Specification & 1997 & 2001 & 2005 & 2007 \\
\hline \multicolumn{5}{|c|}{ POSITION 1} \\
\hline Incumbent and Gov. Party & $\begin{array}{r}0.12^{*} \\
(0.07)\end{array}$ & $\begin{array}{c}0.02^{*} \\
(0.01)\end{array}$ & $\begin{array}{c}0.03^{*} \\
(0.01)\end{array}$ & $\begin{array}{r}0.02^{*} \\
(0.01) \\
\end{array}$ \\
\hline Non-Incumbent and Gov. Party & $\begin{array}{c}0.25^{*} \\
(0.11)\end{array}$ & $\begin{array}{r}0.06^{*} \\
(0.02)\end{array}$ & $\begin{array}{r}0.07^{*} \\
(0.02)\end{array}$ & $\begin{array}{r}0.04^{*} \\
(0.02) \\
\end{array}$ \\
\hline Non- Gov. Party and Non-Incumbent & $\begin{array}{r}0.25^{*} \\
(0.11)\end{array}$ & $\begin{array}{r}0.06^{*} \\
(0.02)\end{array}$ & $\begin{array}{r}0.07^{*} \\
(0.02)\end{array}$ & $\begin{array}{r}0.04^{*} \\
(0.02) \\
\end{array}$ \\
\hline Non-Gov. Party and Incumbent & $\begin{array}{r}-0.01 \\
(0.05) \\
\end{array}$ & $\begin{array}{r}-0.01 \\
(0.02) \\
\end{array}$ & $\begin{array}{r}-0.01 \\
(0.02) \\
\end{array}$ & $\begin{array}{r}-0.002 \\
(0.006) \\
\end{array}$ \\
\hline \multicolumn{5}{|c|}{ POSITION 2} \\
\hline Incumbent and Gov. Party & $\begin{array}{l}-1.06^{*} \\
(0.57)\end{array}$ & $\begin{array}{l}-1.12^{*} \\
(0.73)\end{array}$ & $\begin{array}{l}-0.93^{*} \\
(0.54)\end{array}$ & $\begin{array}{l}-0.85^{*} \\
(0.43) \\
\end{array}$ \\
\hline Non-Incumbent and Gov. Party & $\begin{array}{r}-0.59 \\
(0.66)\end{array}$ & $\begin{array}{l}-0.63 \\
(0.73)\end{array}$ & $\begin{array}{r}-0.54 \\
(0.65)\end{array}$ & $\begin{array}{l}-0.43 \\
(0.53)\end{array}$ \\
\hline Non- Gov. Party and Non-Incumbent & $\begin{array}{r}-0.59 \\
(0.70)\end{array}$ & $\begin{array}{l}-0.62 \\
(0.73)\end{array}$ & $\begin{array}{r}-0.55 \\
(0.65)\end{array}$ & $\begin{array}{r}-0.45 \\
(0.52) \\
\end{array}$ \\
\hline Non-Gov. Party and Incumbent & $\begin{array}{r}-0.51 \\
(0.52) \\
\end{array}$ & $\begin{array}{r}-0.57 \\
(0.60) \\
\end{array}$ & $\begin{array}{r}-0.47 \\
(0.45) \\
\end{array}$ & $\begin{array}{r}-0.42 \\
(0.38) \\
\end{array}$ \\
\hline \multicolumn{5}{|c|}{ POSITION 3} \\
\hline Incumbent and Gov. Party & $\begin{array}{r}0.02 \\
(0.43)\end{array}$ & $\begin{array}{l}-0.02 \\
(0.41)\end{array}$ & $\begin{array}{r}-0.01 \\
(0.39)\end{array}$ & $\begin{array}{r}0.01 \\
(0.43) \\
\end{array}$ \\
\hline Non-Incumbent and Gov. Party & $\begin{array}{l}-0.06 \\
(0.66)\end{array}$ & $\begin{array}{l}-0.12 \\
(0.61)\end{array}$ & $\begin{array}{c}-0.14 \\
(0.62)\end{array}$ & $\begin{array}{l}-0.09 \\
(0.59)\end{array}$ \\
\hline Non-Gov. Party and Non-Incumbent & $\begin{array}{l}-0.08 \\
(0.64)\end{array}$ & $\begin{array}{c}-0.11 \\
(0.61)\end{array}$ & $\begin{array}{l}-0.12 \\
(0.59)\end{array}$ & $\begin{array}{l}-0.08 \\
(0.64)\end{array}$ \\
\hline Non-Gov. Party and Incumbent & $\begin{array}{c}0.52 \\
(0.44) \\
\end{array}$ & $\begin{array}{c}0.46 \\
(0.36)\end{array}$ & $\begin{array}{c}0.44 \\
(0.37) \\
\end{array}$ & $\begin{array}{c}0.51 \\
(0.42) \\
\end{array}$ \\
\hline
\end{tabular}

Numbers in parentheses are standard errors; * $p<0.05$ 
Those in the second position on party lists seem to benefit significantly and substantially from the negative impact of increases in unemployment on the list leaders, albeit only if they are from the governing party and if they are incumbent candidates. For each election year, an increase in unemployment helps those candidates to move to the top of the list (i.e. by approximately one position). Non-incumbent candidates and incumbents from non-governing parties neither experience a similar benefit nor are they affected negatively. The same holds for those listed in the third position irrespective of their incumbency status or party ID.

At the same time, it is worth noting that not only PM Party candidates but also non-PM party candidates are punished for bad economic results. This finding could be related to the specificity of the PR electoral system where it is usually difficult to create a majority one-party government and, thus, not only the governing party but also coalition partners may seem to voters to be responsible for economic results. In addition, minority governments are often formed in PR systems. This is precisely the case in Poland where during the time period studied parties have either governed as a coalition or as a minority government. While under coalition government junior parties may take some of the blame, in a minority government situation not only the governing party but also opposition parties may be viewed as responsible for economic results, since to enact any law, the opposition must co-operate with the governing party. Lack of cooperation may also negatively impact both sides as voters grow tired of bickering and gridlock and blame all parties for unsatisfactory economic results. Why do non-governing party incumbents not suffer under these conditions? If one assumes that in a PR system voters distribute responsibility to all parties, parties in power should suffer more under negative economic conditions than the opposition (or junior coalition) parties. It is possible that while incumbency advantage cannot counter this negative impact for the governing party candidates, it may have this effect for non-governing party candidates. Figures 2 and 3 illustrate the changes in the first position and changes in position 1 and 2 for the governing party's incumbent candidates.

At first sight, the results of simulations reveal the small effect of the economy. In fact, however, advancement by a whole position from second to first place on the list is substantial as it raises the chances of becoming re-elected. Most importantly, this effect is significant for incumbent candidates and governing parties, confirming the main argument advanced in this work, that economic voting exists if voting is considered as a twostage decision. Just as in the traditional economic voting literature, here the incumbency of a candidate and party also play a key role, providing voters with cues about whether to punish or reward a candidate based on economic results.

In addition to the effect of the main variables of interest, the effect of some other variables is noteworthy. Again, governing party status does not help as we do not note "incumbency advantage" with respect to parties. Being a candidate of a governing party 


\section{Change in the First Position}

\begin{tabular}{|c|c|c|c|c|}
\hline \multicolumn{5}{|l|}{$\begin{array}{r}0.3 \\
0.25\end{array}$} \\
\hline \multicolumn{5}{|l|}{0.15} \\
\hline & & & & \\
\hline 0 & 1997 & 2001 & 2005 & 2007 \\
\hline $\begin{array}{c}\text {-Incumbent Candidate } \\
\text { from PM Party }\end{array}$ & 0.12 & 0.02 & 0.03 & 0.02 \\
\hline $\begin{array}{c}\text { Non-incumbent } \\
\text { Candidate from PM } \\
\text { Party }\end{array}$ & 0.25 & 0.06 & 0.07 & 0.04 \\
\hline $\begin{array}{l}\text { Non-Incumbent } \\
\text { Candidate from Non- } \\
\text { governing Party }\end{array}$ & 0.25 & 0.06 & 0.07 & 0.04 \\
\hline
\end{tabular}

Figure 4

\section{Change in Position for the Governing Party's Incumbent Candidates}

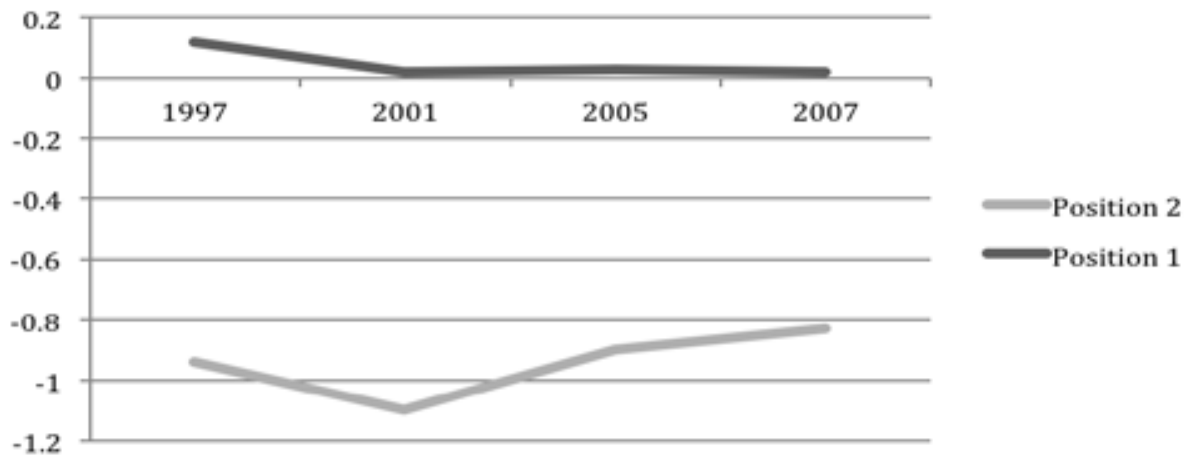

Figure 5

does not matter in terms of changes in position. This is an important finding. With all else equal, voters treat candidates the same, irrespective of which party these candidates come from. There is not a built-in benefit or disadvantage to being a governing or opposition party's top candidate.

Still, incumbent advantage seems to work for individual candidates since incumbents are less likely than non-incumbents to change their position to a lower one as a result of voters' intervention. List position also matters. Those incumbents listed first on the list are less likely to fall than those listed later on the list. This may be related to the primacy effect as mentioned by Miller and Krosnick (1998), according to which if voters have no 
knowledge of candidates but like the party, they will be more likely to vote for the person listed first on the list despite the fact that they do not know much about this person. On the other hand, those listed first on the list as prominent candidates may have been advertised more than others by the party and become more known to voters or were more known to the voters to begin with. Therefore, voters are more likely to vote for the candidates they recognize.

The district magnitude variable works as predicted for all positions. The larger the district magnitude, the more potential rivals each of the candidates has in a district and the larger their chances are of falling from their initially high positions or the smaller the chances they have of advancing. The strength of the candidate's party in the district does not matter for any of the positions, and nor do changes in unemployment levels alone matter. Being a female candidate has different effects for the first, second and third positions. Female candidates listed first are more likely to fall from their positions than male candidates but those listed second or third are less likely to fall than their male counterparts.

\section{Conclusion}

Economic voting is a well-established concept within research focusing on political accountability. Voters punish incumbents when the economy is doing badly and reward them when it is doing well. In this setting politicians are agents who act within the political realm with voters acting as principals. This paper contributes to this body of work as it takes the first step to considering preferential voting as a vehicle for assigning responsibility to parties and candidates. To do so it re-conceptualizes the act of voting itself. While until now researchers have usually viewed it as a one stage decision, here voting is conceptualized as a two stage process: one stage in which voters decide which list (party) to choose and a second stage where voters, having decided their preferred party, decide which candidate on the list they prefer.

As shown in the example of Polish legislative elections, voters take this opportunity and assign responsibility to the parties at the second stage of the vote by negatively impacting the incumbent count or candidates' positions on the list. Interestingly, only governing party candidates listed first on the list are negatively impacted by a bad economy, which indicates that Party and not Candidate Accountability is at work. This seems to be a confirmation of the conclusions Zielinski et al. (2005) came to in their research on Polish legislative elections: that incumbents seem to be able to hide behind party labels to avoid responsibility. Parties seem to be held accountable by voters as their "showcase candidates" fall down the list when economic results are not satisfactory to voters. And even though they do not fall far, as voters seem to opt for the candidate "next in line," the 
move may have an impact on who will enter parliament in small districts and districts where the governing party's support is particularly weak, either due to historical weakness in this area or due to general vulnerability in the elections. ${ }^{46}$ For individual candidates, this result implies that the first position, so much sought after by candidates in PR elections, may not always be to their benefit. All in all, candidates in open-list systems should possibly rethink their strategy under conditions of bad economic results if their goal is to be elected or re-elected.

Albeit only devised in a one-country context, these findings are very important on theoretical and empirical grounds. Theoretically, they urge scholars to reconsider the way they operationalize voting under open list designs. Empirically, this work provides evidence of accountability under open-list design at both stages of voting. Most importantly, it finds that the traditional measures of accountability are insufficient for openlist systems. When the second stage of voting is considered, accountability gains a new dimension. The evidence of accountability in the second stage of voting suggests that an open-list PR electoral system may be better and more conducive to accountability than we thought. Until now, PR systems have been considered less responsive to voters due to lower accountability than majoritarian systems. In exchange, PR systems have been described as more representative. This research suggests that preferential PR systems may offer a middle ground for those trying to find both high representativeness and high accountability. Voters under open-list arrangements seem to be able to use those systems to their advantage. They can even have their cake and eat it, too, by voting for their party while punishing it if they feel the party's performance in office was not good enough.

46 Interestingly, those listed third on the list are not affected by the economy, which only confirms my decision to look only at the top slate of candidates. 
192 | Adam Mickiewicz University Law Review

\section{Appendix 3}

\begin{tabular}{cccrrr}
\hline \multicolumn{2}{c}{ Table 3.1 } & & & \\
& Summary Statistics & & & \\
\hline Variable & $\mathrm{N}$ & Mean & Std. Dev. & Min & Max \\
\hline Change in Position & 39573 & 0.00 & 4.63 & -30 & 35 \\
\hline Change in Position No. 1 & 2712 & 0.23 & 0.88 & 0 & 23 \\
\hline Change in Position No. 2 & 2708 & 2.25 & 2.07 & 0 & 30 \\
\hline Change in Position No. 3 & 2710 & 3.34 & 2.48 & 0 & 32 \\
\hline Incumbent Difference & 39573 & -0.23 & 1.38 & -9 & 5 \\
\hline Incumbent & 39571 & 0.04 & 0.21 & 0 & 1 \\
\hline PM Party & 39572 & 0.12 & 0.33 & 0 & 1 \\
\hline District Magnitude & 39573 & 11.04 & 4.55 & 3 & 46 \\
\hline District Magnitude (ln) & 39573 & 2.33 & 0.40 & 1.10 & 3.829 \\
\hline Sum of incumbents & 39573 & 0.84 & 1.23 & 0 & 8.000 \\
\hline No of incumbents on a list & 39573 & 0.45 & 0.54 & 0 & 2.197 \\
\hline (ln) & & & & & \\
\hline Incumbents reelected & 39573 & 1.07 & 1.75 & 0 & 11.000 \\
\hline Vote share & 39572 & 9.79 & 11.69 & 0.03 & 97.350 \\
\hline Vote share (ln) & 39572 & 1.49 & 1.44 & -3.51 & 4.578 \\
\hline No. of votes for a list & 31074 & 36404.51 & 53271.29 & 127 & 618942 \\
\hline Female & 39573 & 0.20 & 0.40 & 0 & 7 \\
\hline & & & & &
\end{tabular}




\section{Appendix 4}

\section{Table 4.1 \\ OLS Regression: Change in List Position}

\begin{tabular}{|c|c|c|c|c|c|c|}
\hline & Position 1 & Position 2 & Position 3 & Position 4 & Position 5 & Position 6 \\
\hline \multirow{2}{*}{ Incumbent } & $0.136^{*}$ & $0.998^{* * *}$ & $1.437^{* * *}$ & $1.664^{* * * *}$ & $2.710^{* * * *}$ & $1.599^{* *}$ \\
\hline & $(0.06)$ & $(0.17)$ & $(0.25)$ & $(0.34)$ & $(0.45)$ & $(0.58)$ \\
\hline \multirow{2}{*}{ District Magnitude (ln) } & $-0.182^{*}$ & $-0.672^{* * * *}$ & $-1.076^{* * *}$ & $-1.087^{* * *}$ & $-1.407^{* * * *}$ & $-1.483^{* * *}$ \\
\hline & $(0.07)$ & $(0.16)$ & $(0.19)$ & $(0.22)$ & $(0.25)$ & $(0.26)$ \\
\hline \multirow{2}{*}{ Vote share $(\ln )$} & -0.017 & 0.032 & 0.088 & -0.046 & -0.094 & $-0.143^{*}$ \\
\hline & $(0.02)$ & $(0.04)$ & $(0.05)$ & $(0.06)$ & $(0.06)$ & $(0.07)$ \\
\hline \multirow{2}{*}{ PM Party } & 0.023 & -0.141 & -0.079 & -0.115 & 0.449 & 0.426 \\
\hline & $(0.08)$ & $(0.17)$ & $(0.21)$ & $(0.24)$ & $(0.26)$ & $(0.27)$ \\
\hline \multirow{2}{*}{ Female } & -0.070 & $0.421^{* * *}$ & $0.327^{*}$ & $1.156^{* * *}$ & $0.847^{* * *}$ & $0.554^{* *}$ \\
\hline & $(0.06)$ & $(0.13)$ & $(0.14)$ & $(0.17)$ & $(0.19)$ & $(0.20)$ \\
\hline Change in & -0.004 & -0.004 & -0.017 & 0.016 & 0.007 & 0.004 \\
\hline Unemployment & $(0.01)$ & $(0.01)$ & $(0.01)$ & $(0.02)$ & $(0.02)$ & $(0.02)$ \\
\hline Incumbent X Chng. In & 0.004 & 0.013 & 0.000 & 0.008 & 0.035 & 0.004 \\
\hline Unemployment & $(0.00)$ & $(0.01)$ & $(0.01)$ & $(0.02)$ & $(0.02)$ & $(0.03)$ \\
\hline \multirow{2}{*}{$\begin{array}{c}\text { PM Party X Chng. In } \\
\text { Unemployment }\end{array}$} & $-0.008^{*}$ & 0.014 & 0.018 & -0.006 & 0.012 & -0.002 \\
\hline & $(0.00)$ & $(0.01)$ & $(0.01)$ & $(0.01)$ & $(0.01)$ & $(0.01)$ \\
\hline \multirow{2}{*}{$\begin{array}{l}\text { Total Incumbents- In- } \\
\text { cumbents reelected }\end{array}$} & 0.007 & -0.042 & 0.103 & 0.057 & $-0.151^{*}$ & -0.105 \\
\hline & $(0.02)$ & $(0.05)$ & $(0.05)$ & $(0.06)$ & $(0.07)$ & $(0.07)$ \\
\hline \multirow{2}{*}{ Election 1997} & $-0.430^{*}$ & $-0.640^{* * *}$ & -0.318 & 0.111 & $1.707^{*}$ & $1.596^{*}$ \\
\hline & $(0.22)$ & $(0.17)$ & $(0.56)$ & $(0.23)$ & $(0.72)$ & $(0.76)$ \\
\hline \multirow{2}{*}{ Election 2001} & 0.000 & -0.446 & 0.000 & -0.367 & 0.000 & 0.000 \\
\hline & (.) & $(0.48)$ & (.) & $(0.66)$ & (.) & (.) \\
\hline \multirow{2}{*}{ Election 2005} & -0.042 & -0.189 & 0.013 & -0.552 & 0.389 & -0.064 \\
\hline & $(0.08)$ & $(0.39)$ & $(0.21)$ & $(0.52)$ & $(0.27)$ & $(0.28)$ \\
\hline \multirow{2}{*}{ Election 2007} & -0.047 & 0.000 & -0.201 & 0.000 & 0.586 & 1.100 \\
\hline & $(0.22)$ & (.) & $(0.57)$ & (.) & $(0.72)$ & $(0.77)$ \\
\hline \multirow{2}{*}{ Constant } & 0.300 & 0.261 & 0.713 & 0.835 & 0.892 & 1.537 \\
\hline & $(0.23)$ & $(0.41)$ & $(0.59)$ & $(0.57)$ & $(0.76)$ & $(0.81)$ \\
\hline R-sqr & 0.022 & 0.048 & 0.062 & 0.062 & 0.094 & 0.087 \\
\hline $\mathrm{N}$ & 1851 & 1849 & 1850 & 1837 & 1810 & 1784 \\
\hline
\end{tabular}

Numbers in parentheses are standard errors; ${ }^{*} p<0.05,{ }^{* * *} p<0.01,{ }^{* * * * *} p<0.001$ 
I decided to focus on the first 6 positions only. This has both pragmatic as well as substantive grounds.

It will simplify my analysis and provide clearer results. More importantly, there is a valid reason to assume that only the candidates listed in the early positions are in fact recognizable to voters. Also, these are the obvious "showcase candidates" of particular parties.

Table 5.2 presents the OLS results when Model 1 is applied for the first 6 positions. The coefficient of the incumbency variable is always highly statistically significant and positive. A positive coefficient in this case means a drop down the list since a higher placement value equals a lower position. Candidates across all six positions are affected negatively by incumbency. Still, those listed earlier lose less than those who are listed later on the list. This is an unexpected result, since informed by previous research we expected incumbents to have the advantage over non-incumbents. Interestingly, the disadvantage decreases as we move to the top of the list. Those listed first are affected negatively by incumbency twenty times less than those listed fifth on the list.

A noteworthy result reveals the effect of unemployment or rather lack thereof across the candidates in most cases. Nor does incumbency status condition the impact of the unemployment variable. The only impact of unemployment we find is for governing party candidates who are listed in the first position on the list. When unemployment rises, those who are listed first seem to benefit. This is a finding that contradicts my expectations about economic voting at the second stage of the vote. 
To bave your cake and eat it too: accountability under a preferential voting system... 195

\section{Appendix 5}

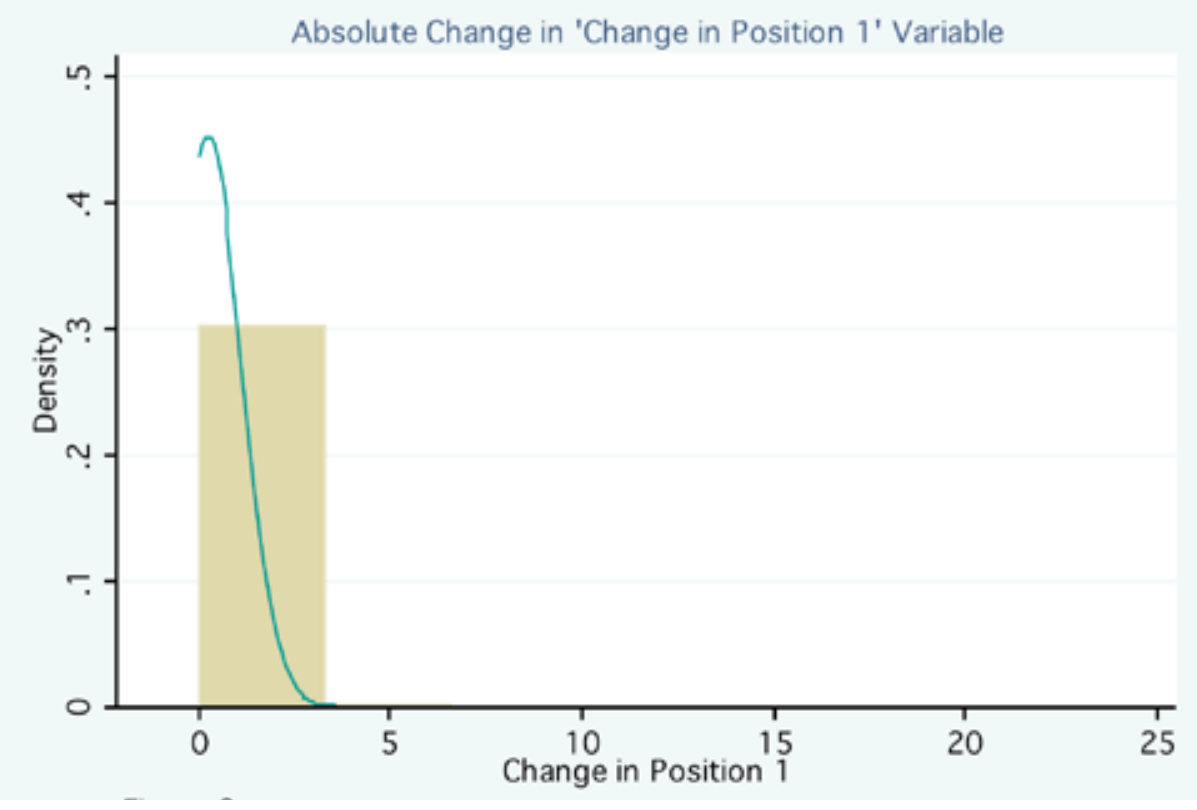

Figure 5.1

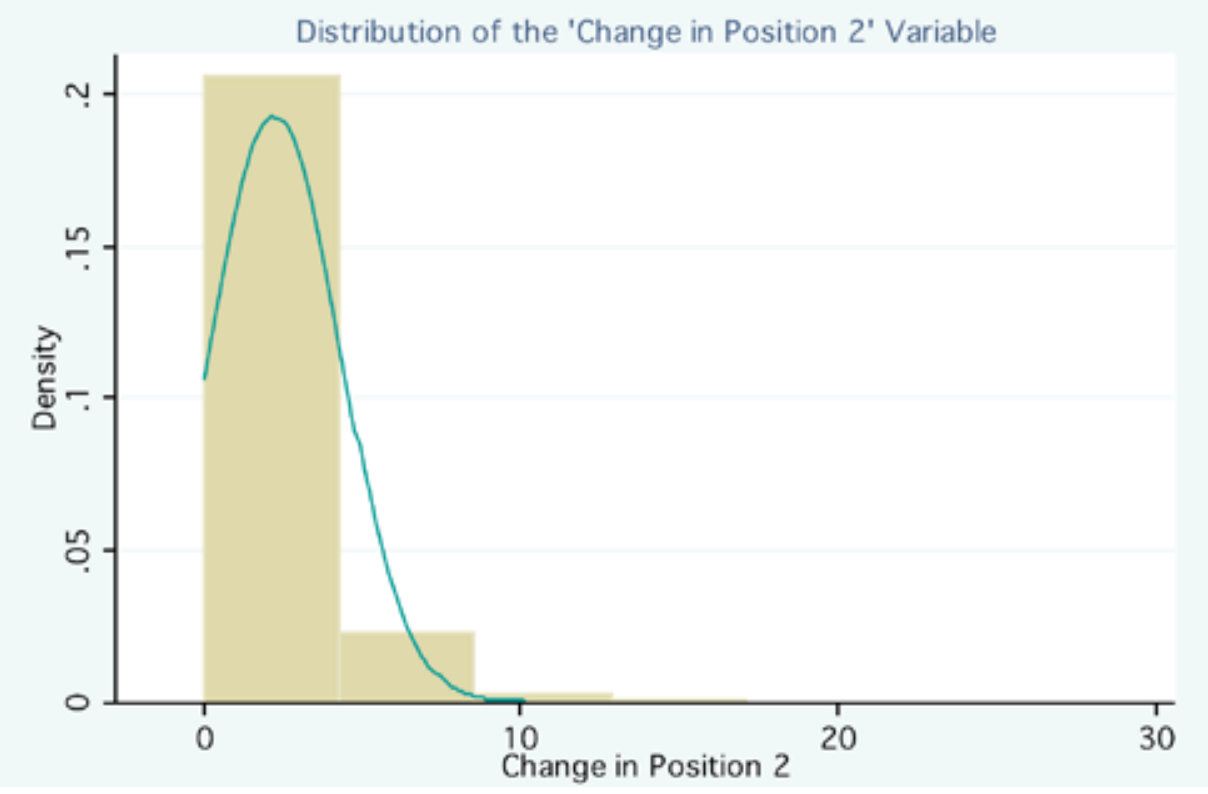

Figure 5.2 


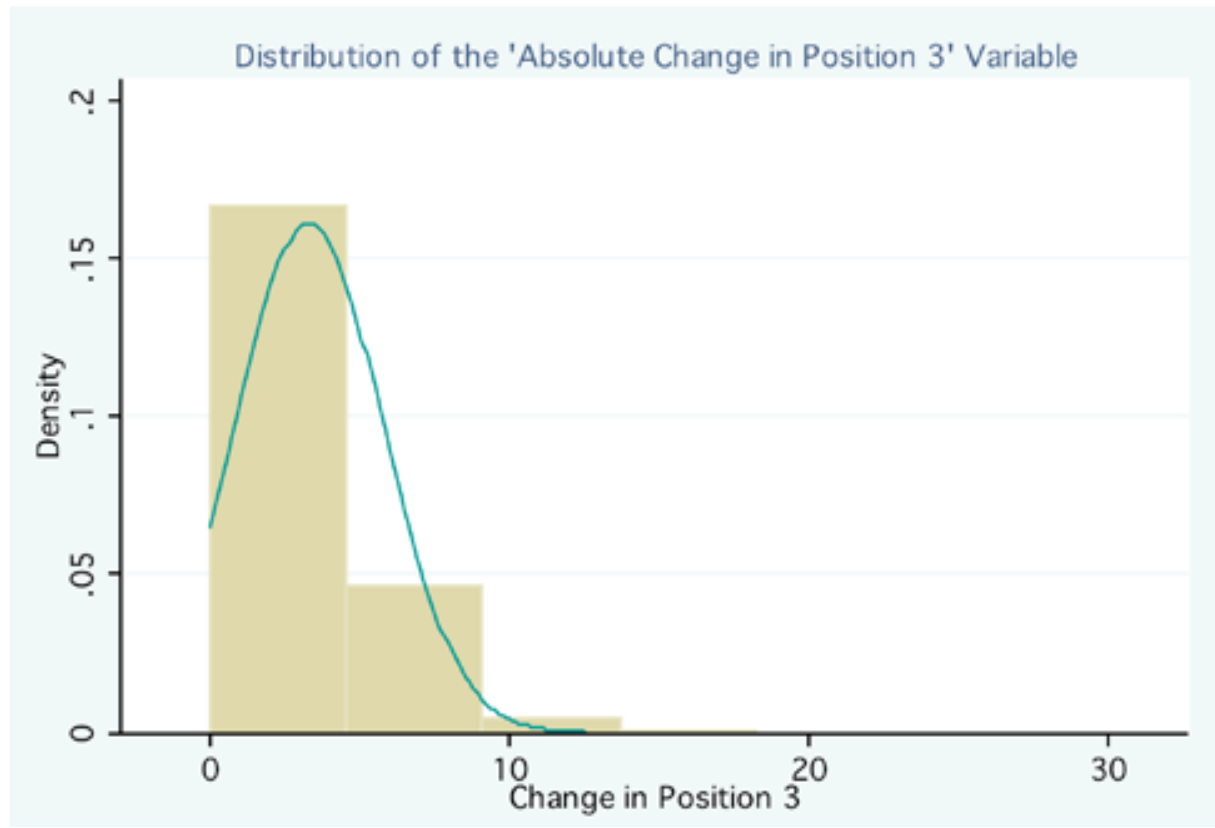

Figure 5.3

Since the values are non-normal, OLS estimation would be flawed. I consider two possible maximum likelihood estimation techniques: Poisson and negative binomial regression. The statistical model needs to account for two very specific features of the data distribution. Poisson and negative binomial regressions are very similar to each other as they both allow for the recognition of the skewed distribution of probabilities for advancing/falling on the list and better model the relationship that we observe with open list electoral systems. My dependent variable includes only positive values and is skewed to the left, which fits both Poisson and negative binomial estimation. Poisson models presume that the variance fits exactly, i.e. all counted events follow the same distribution. In contrast, negative binomial estimation includes an error term accounting for variance around the estimated means. Thus, while for Poisson we compute probabilities by computing $\exp (\alpha+\beta x)$, for negative binomial we compute exp $(\alpha+\beta x) * \exp$ (error) which is nothing more than $\exp (\alpha+\beta \mathrm{x}){ }^{*}$ alpha, where alpha is the dispersion parameter that adds the possible variance to the model. Thus, having alpha significant in the model means that heterogeneity is present and we should use negative binomial that does not assume homogeneity. While Poisson regression assumes that all counted events follow the same distribution, the negative binomial allows for variance, i.e. adds the error term.

The parameter alpha is statistically significant in all my models (alpha is statistically different than zero) presented in Table 2 (in the text), which means that the data is overdispersed and negative binomial regression is a better fit for the data than the Poisson 
model. Also, other fit statistics such as AIC and BIC confirm the choice of negative binomial over Poisson (see Table 2 in the text).

I have also checked whether zero inflated negative binomial estimation is not more appropriate for my model when the dependent variable is an Absolute Change in Position 1 . The zero inflated negative binomial estimation is useful in cases where the number of zeros is excessive and the zero values cannot be explained in the same way as the non-zero ones. As Figure 3 in Appendix 5 indicates and Table 5.1 shows in detail, there is an inflated number of zeros for those candidates listed first on the list (i.e. most of the candidates remain in their position).

Therefore, I need to test whether zero inflated negative binomial regression is more appropriate for estimating Absolute Change in Position 1. This does not seem to be the case for Absolute Change in Position 2 and 3 (See Table 1). For the candidates listed in the second and third positions by their party, their values for dropping/advancing on the list are much more uniformly distributed and therefore regular negative binomial estimation can be applied.

To test which regression fits the data better, I run the zero inflated negative binomial estimation where the dependent variable is presumed to be inflated by the variables related to incumbency, governing party status, and unemployment. Having done this, I apply the Vuong test. Statistically significant z-values for this test suggest that a zeroinflated negative binomial is a better choice for a specific set of data. This is not the case with regards to my data, however. The Vuong test produces a $\mathrm{z}$-value of $0.95 \operatorname{Pr}>\mathrm{z}=0.17$ ), which is not statistically significant at customarily accepted significance levels. 


\section{Table 5.1}

Distribution (Frequency) of the "Absolute Change" Variables

\begin{tabular}{|c|c|c|c|}
\hline Position & $\begin{array}{c}\text { Absolute Change From } \\
\text { Position } 1\end{array}$ & $\begin{array}{c}\text { Absolute Change From } \\
\text { Position } 2\end{array}$ & $\begin{array}{c}\text { Absolute Change } \\
\text { From Position } 3\end{array}$ \\
\hline 0 & 2300 & 201 & 69 \\
\hline 1 & 314 & 1097 & 516 \\
\hline 2 & 66 & 560 & 654 \\
\hline 3 & 17 & 354 & 500 \\
\hline 4 & 4 & 185 & 327 \\
\hline 5 & 4 & 123 & 209 \\
\hline 6 & 1 & 76 & 157 \\
\hline 7 & 1 & 38 & 105 \\
\hline 8 & 2 & 32 & 67 \\
\hline 9 & 1 & 16 & 35 \\
\hline 10 & - & 12 & 27 \\
\hline 11 & - & 4 & 13 \\
\hline 12 & - & 1 & 12 \\
\hline 13 & - & 3 & 4 \\
\hline 14 & - & 1 & 6 \\
\hline 15 & - & 1 & 5 \\
\hline 16 & - & 1 & 2 \\
\hline 17 & - & 1 & - \\
\hline 19 & 1 & - & 1 \\
\hline 22 & 1 & - & - \\
\hline 23 & - & - & - \\
\hline 24 & - & 1 & - \\
\hline 30 & - & 1 & - \\
\hline 32 & - & - & 1 \\
\hline Total & 2712 & 2708 & 2710 \\
\hline
\end{tabular}

\section{SUMMARY}

To have your cake and eat it too: accountability under a preferential voting system

Informed by the findings in the economic voting literature and using an original dataset on Polish elections this research breaks away from this established practice and goes a step further by showing how economic conditions allow voters to distinguish between high/low performers and effectively attribute responsibility under open-list PR systems where voters can choose not only among parties but also among individual candidates. By integrating open-list design into the model of accountability this study transforms the way we think about the very act of voting.

Keywords: Voting rights regulations, preferential voting system, accountability system 